\title{
Factor of Adoption of Organic Cotton in Southern Mali in the Villages of Kolodieba and Yanfolila
}

\author{
Boubacar Keita ${ }^{1} \quad$ Xiuqin Liu ${ }^{1 *} \quad$ Youssouf Traore $^{2} \quad$ Morike Konate $^{3}$ \\ 1.School of Mathematics and Physics, University of Sciences and Technology Beijing, China \\ 2.School of Economics and Management, Beihang University, Beijing, China \\ 3.School of Mathematics and Statistics, Changsha University of Sciences and Technology, Changsha, China \\ * E-mail of the corresponding author: sixinhui_ustb@126.com
}

\begin{abstract}
Organic cotton has started in 2004 in Mali in the context of a serious crisis in the conventional cotton production system. It is all the more important for developing countries like Mali where agriculture, one of the pillars of the economy, remains heavily dependent on chemical pesticides. The aim of this study is to analyze the adoption of organic cotton production in the villages of Kolondieba and Yanfolila in southern Mali. Our survey involved 114 people including 48 organic cotton producers and 67 conventional cotton producers. Data were collected through individual interviews based on questionnaires. The analysis of the adoption of organic cotton carried out using a logistic regression model showed that the socio-economic characteristics of producers as well as the sex and education of producers are the main factors influencing their choice of production or not organic cotton. Women prefer organic production more than conventional production. This allows them not to depend on their husbands for inputs but also to have their own fields. Producers who have a very large number of people in the family, producers with schooling, as well as producers with a lot of beef are more apt to adopt organic cotton.
\end{abstract}

Keywords: Adoption, Socio-economic factors, Organic cotton

DOI: $10.7176 / \mathrm{JESD} / 12-10-03$

Publication date:May $31^{\text {st }} 2021$

\section{Introduction}

Agriculture, the engine of the Malian economy, employs more than $75 \%$ of the working population, contributes $44 \%$ of the gross domestic product (GDP) and $15 \%$ of the value of exports (http://afribonemali.net). In fact, cotton represents $62 \%$ of the country's agricultural exports (Deshpande, 2017). In Mali, cotton or "white gold" plays a key role in the Malian economy (RuralStruc-Mali2, 2009). Cultivated by more than 300,000 family farms (EAF) in the Mali-South and Kita zones, it provides income to 1/3 of the Malian population (World Bank, 2016). Mali, one of the leading cotton producers in West Africa with a record production of 645,000 tons of seed cotton, for a guaranteed price to producers of $250 \mathrm{~F} \mathrm{CFA} \mathrm{/} \mathrm{kg,} \mathrm{was} \mathrm{recorded} \mathrm{in} \mathrm{2016/2017} \mathrm{(} \mathrm{http://malinet.com).} \mathrm{The} \mathrm{economic}$ and social advantages linked to cotton cultivation must not hide significant constraints: the climate (random rainfall and unevenly distributed in time and space), difficult access to inputs (mineral fertilizers, herbicides, insecticides, etc. .) and agricultural equipment, the decline in soil fertility and the effect of pests on cotton (Ge et al., 2003). The non-organic sector represents the most important production (Tayade \& Dhoble, 2010). The latter uses both fertilizer and pesticides. Finally, to double these productions in 5 years (2014-2018), the Malian government has increased the subsidy for chemical fertilizers. The use of pesticides ensures a good yield of the cotton crop and reduces losses due to pests or diseases (Farooq et al., 2020). The use of these chemical inputs contributes to the degradation of nature and a bad impact on health. For years, notable efforts have been made to develop environmental sustainability through a clear reduction in inputs (De Guimaraes et al., 2014) . Successive cotton production methods, qualified and judged more respectful of the environment and human health than the conventional system, are thus promoted for the benefit of producers. These sustainable systems include those for organic cotton production and cotton made in Africa (Assogba et al., 2014).

The program for the production of organic cotton in Mali has the following objectives: access to a cash crop for a greater number of small producers, diversification of marketing markets, reduction of the use of pesticides, creation of wealth and reduction of inequity according to the Swiss NGO Helvetas program (Holcombe et al., 2004).

The first experience of organic cotton cultivation in Mali began around 1999. And every year there are new members. A few years ago I had few adherents to the cultivation of organic cotton. Recent statistics show that cotton producers are gradually starting to take an interest in organic cotton production. This is why we wonder what are the reasons that push new members to adopt organic cotton or not.

To answer this questioning that this study was conducted. Led by the NGO Helvetas was carried out in two zones in Mali-South of Yanfolila and Kolondieba. This study aims to analyze the factors influencing the adaptation of organic cotton. 
2 Methodology

\subsection{Area of Intervention: Yanfolila and Kolondieba}

The choice of the intervention area is Yanfolula and Kolondieba because of the large number of cotton growers in this area. These are areas of relatively recent cotton expansion. The cotton culture is relatively refocused. Cotton cultivation began to develop there from the 1980s. Today almost all of the farms cultivate cotton over an area of 2-3 hectares on average.

The agricultural land potential of the two zones is significant. Overall, agricultural land reserves reached 2/3 of the total; this potential is greater in Yanfolila than in Kolondieba. The pluviometric conditions are also favorable; the average pluviometric in the zone of Yanfolila reaches $1300 \mathrm{~mm}$ against $1100 \mathrm{~mm}$ in Kolondieba. The equipment rate of farms is considered to be low and many villages are totally enclaves during the rainy season (August-September).

The average yield of conventional cotton in these areas is around $1061 \mathrm{~kg} /$ ha cotton grain. In general, yields are higher in Yanfolila than in Kolondieba. Thanks to the sufficient reserves of agricultural land, the practice of fallow is widespread while the time of fallow varies greatly from case to case. Transhumant herds stay in these two areas during the dry season, but the potential for organic manure represented by these animals is insufficiently exploited.

\subsection{Methodological Approach}

This study aims to analyze the factors influencing the adaptation of organic cotton. They are the first experiences based on observations and positive experiences with organic cotton, that is to say cotton produced without the use of chemical inputs, in other countries of the sub-region. region (eg Benin and Senegal) in 1999 with the participation of volunteer producers, in Yanfolila and Kolondieba. To do our study took a sample of 114 producers was randomly made up of which 67 conventional cotton producers and 48 organic cotton producers. The survey was carried out by the NGO Helvetas in collaboration with the CMDT (Lakhal et al., 2005). Each producer was questioned to know the demographic and socio-economic characteristics and the reasons for adopting organic cotton. They get the information by doing individual interviews based on fact sheets.

\subsection{Statistical Study of the Data}

The study of the influencing factors the analysis of the factors influencing the adoption of organic cotton was carried out using a logistic regression model with SPSS (Statistical Package for Social Sciences) software. Let us see by the adoption in this study, the decision of the producer to gradually join the production of organic cotton on his farm. Thus, the practitioner is the one who produces organic cotton for at least a year and who still continues this production. It is assumed that this specific period (a cotton campaign) would have allowed the adopter not only to be sufficiently informed about organic cotton, to know the satisfaction that results from it and to be able to decide whether or not to continue producing cotton forever. Biological (Altenbuchner et al., 2016).

\subsection{Choice and Justification of the Model}

Four econometric models are generally used to explain the reasons for adopting agricultural innovations. These are the linear regression model and the Logit, Probit and Tobit logistic regression models (Wilson \& Lorenz, 2015) . The first model is not credible because its probability can exceed 1 . The Tobit model (or censored normal regression model) allows to take into account the censorship of data concerning the intensity of adoption by assuming that both the determinants and the effects of the determinants are identical for the probability of adoption and for the intensity of this adoption (Arslan et al., 2014). This is not the objective pursued in this study. The Logit model is based on the logistic law of probability distribution while the Probit model is based on the normal distribution. These two models lead to similar results (Li et al., 2013) cited by (Holland \& Gray, 2011). Therefore, there is no persuasive reason to choose one over the other. Practically, many researchers adopt the Logit model because it is mathematically still simple (Eichelberger, 2007). It is mainly for reasons of convenience that the logistic regression model (Logit) was used in this analysis as it was the case numerous adoption studies in agriculture (Holland \& Gray, 2011; Nguyen et al., 2013) Since the dependent variable in our case can only take two values (0 and 1), binomial Logit was applied for this analysis.

This model looks like this:

$Y=f(X, e)$

$Y:$ dependent variable

$X:$ matrix of variables likely to explain the variation of $\mathrm{Y}$

$e: \operatorname{logistics}$ error in distribution

The evaluation of our Logit model is based on the maximum likelihood method.

Let $P i$ be the probability that the Logit associates with the survey unit: 


$$
\begin{aligned}
& P i=F\left(I_{i}\right)=\frac{1}{1+e^{-I_{i}}} \\
& I=\beta_{0}+\beta_{1} X_{i 1}+\beta_{2} X_{i 2}+\beta_{3} X_{i 3}+\ldots+\beta_{n} X_{i n}
\end{aligned}
$$

It is a vector which suggests the characteristics of the unit of inquiry, of its environment and of the object of its choice; they $\beta_{i}$ represent the coefficient of explanatory; they ${ }^{\text {in }}$ represent the explanatory variables.

The decision to choose organic cotton is made exclusively when the combined effect of the factors reaches a critical value, from which the individual accepts to produce organic. Assuming that the effect is measured by an unobservable index for ${ }^{I}$ the individual, and ${ }^{I}$ the critical value of the index from which he decides to opt for organic cotton we have : if $I_{m}$ is greater than $I_{n}$, then the individual chooses to adopt organic cotton and the variable of choice takes the value $Y$ the value 1; otherwise, $Y$ is equal to 0 . The $I_{m}$ higher the critical value, the greater the probability that the individual will choose to adopt organic cotton. The empirical prototype can be written as follows:

$X=\beta_{0}+\beta_{1} A G E+\beta_{2} S E X+\beta_{3} N P F+\beta_{4} A P+\beta_{5} A A C+\beta_{6} E P C+\beta_{7} D H F+\beta_{8} N A W+\beta_{9} \mathrm{Ed}+\beta_{10} N B+\varepsilon_{i}$ With $\mathrm{AGE}=$ Age of the producer, $\mathrm{SEX}=$ Producer sex, $\mathrm{NPF}=$ Number of people in the family, $\mathrm{AP}=\mathrm{The}$ main activity of the producer, $\mathrm{AAC}=$ Acces to agricultural credit, $\mathrm{EPC}=$ Experience in cotton production $\mathrm{DHF}=\mathrm{The}$ distance between the household and the farmer's fields, NAW= The number of agricultural workers in the households surveyed, $\mathrm{Ed}=$ If the producer is educated, $\mathrm{NB}=$ The number of beef available to the producer. $X$ is the explained. The ${ }^{\beta_{i}}$ represent the coefficients of the explanatory variables and ${ }^{\varepsilon_{i}}$ are the error terms. If they $\beta_{i}$ are position and significant then hypothesis $\mathrm{n}^{\circ} 1$ made is verified. Otherwise, it is not.

\subsection{Presentation of the Variables Included in the Model \\ 2.5.1 The explained variable}

The dependent variable of the empirical model is the adoption of organic cotton. This dichotomous qualitative variable is coded PBIOLO and takes the value 1 if the producer has adopted organic cotton and 0 otherwise.

\subsubsection{The explanatory variables: SEX, NPF, AP, AAC, ECP, NAW, Ed, NB}

AGE: This variable designates the age of the producer. A positive effect is expected. In fact, in the literature, the older the respondent, the more he tends to worry about environmental factors. It would therefore be in favor of organic cotton production.

SEX: This variable designates the sex of the producers. It is a binary variable which takes the value 1 for a man and 0 for a woman. We expect a positive sign here because in the literature women are more interested in the production of organic cotton. In this production system, women depend less on their husbands.

NPF: this variable designates the number of people in the family. We expect a positive effect. The greater the number of people in the family, the more positive it is because in the cultivation of organic cotton we need more labor.

AP: This variable designates the main activity of the producer. This variable takes the value 1 if the producer has agriculture as his main activity and 0 for the opposite. We expect a positive sign here. The idea comes from the fact that producers who have agriculture as their main activity are more receptive to innovations, especially those aimed at improving their income.

NAA: This variable designates the number of agricultural workers in the households surveyed. A positive sign is expected as the production of organic cotton is labor intensive. DCM: This variable designates the distance between the household and the fields. We expect a negative sign here. The greater the distance between the respondent's home and their fields, the less trouble they will go there to maintain the crops. However, organic cultivation requires daily maintenance.

EPC: This variable refers to experience in cotton production. According to non-adopting producers, it can be a determining factor in the adoption of organic cotton. We therefore seek to verify this by introducing it into the model. We expect a positive or negative sign.

ACA: This variable designates access to credit by the producer. We expect a positive sign here. Lack of funding has become a constraint for organic producers in the study area.

Scl: This variable indicates whether the producer is in school or not. It is a binary variable that takes the value 1 when the producer is in school and 0 when he is not in school. A positive sign is expected here because people who are educated have knowledge about the degradation of nature by chemicals more than those who are not 
educated.

NB: the number of beef available to the producer can be a positive influencing factor in whether or not to adopt organic cotton production, which places high demands not only on animal labor but also on organic manure. We therefore expect a positive sign.

Table1. Presents a summary of all the variables introduced into the model with their expected sign.

\begin{tabular}{|c|c|c|c|}
\hline Variables & $\begin{array}{l}\text { Type of } \\
\text { variables }\end{array}$ & Description & \\
\hline Adoption (PBIOLO) & $\begin{array}{l}\text { Qualitative } \\
\text { Variable }\end{array}$ & dependent: 1 if the contracts are adopted and 0 if not & \\
\hline Age & Quantitative & Age of producer & + \\
\hline Sex & Qualitative & Producer sex: 1 if the producer is male and 0 if not & + \\
\hline $\begin{array}{l}\text { Number of people in the } \\
\text { family }\end{array}$ & Quantitative & Number of people in the family & + \\
\hline Core business & Qualitative & $\begin{array}{l}\text { Main activity of the producer: } 1 \text { if the producer has } \\
\text { agriculture as his main activity and } 0 \text { for the opposite }\end{array}$ & + \\
\hline $\begin{array}{l}\text { Number of household } \\
\text { agricultural assets }\end{array}$ & Quantitative & Number of household agricultural assets & + \\
\hline $\begin{array}{l}\text { distance between } \\
\text { household and fields }\end{array}$ & Quantitative & distance between household and fields & - \\
\hline $\begin{array}{l}\text { Experience in cotton } \\
\text { production }\end{array}$ & Quantitative & Number of years of experience in cotton production & $+/-$ \\
\hline Access to argicole credit & Qualitative & Access to producer credit: 1 if has access and 0 if not & + \\
\hline Education level & Qualitative & $\begin{array}{l}\text { whether the producer is educated or not: } 1 \text { the producer is } \\
\text { educated and } 0 \text { if he is not }\end{array}$ & + \\
\hline Number of beef & Quantitative & Number of beef available to the producer & + \\
\hline
\end{tabular}

\section{Results}

\subsection{Demographic and Socio-economic Characteristics of Producers}

The demographic and socio-economic characteristics of the producers surveyed are summarized in Table2. Demographic and socio-economic characteristics of producers quantitative

\begin{tabular}{|l|l|l|l|l|l|l|}
\hline Quantitative Variables & \multicolumn{2}{l|}{ Conventional } & \multicolumn{2}{l|}{ Organic } & \multicolumn{2}{l|}{ Together } \\
\cline { 2 - 7 } & Average & $\begin{array}{l}\text { Standard } \\
\text { deviation }\end{array}$ & Average & $\begin{array}{l}\text { Standard } \\
\text { deviation }\end{array}$ & Average & $\begin{array}{l}\text { Standard } \\
\text { deviation }\end{array}$ \\
\hline Age (years) & 49.46 & 9.755 & 46.47 & 5.587 & 48.23 & 8.395 \\
\hline $\begin{array}{l}\text { Number of agricultural } \\
\text { activities }\end{array}$ & 8.51 & 2.613 & 9.06 & 2.335 & 8.74 & 2.507 \\
\hline $\begin{array}{l}\text { Distance between fields } \\
\text { and houses (km) }\end{array}$ & 4.155 & 1.1753 & 4.457 & 7.5552 & 4.280 & 4.9056 \\
\hline Cotton experience (years) & 17.13 & 5.027 & 13.17 & 3.466 & 15.50 & 4.847 \\
\hline $\begin{array}{l}\text { Experience in conventional } \\
\text { cotton (years) }\end{array}$ & 15.87 & 4.539 & 1.17 & 1.404 & 9.81 & 8.101 \\
\hline $\begin{array}{l}\text { Experience in organic } \\
\text { cotton (years) }\end{array}$ & 1.13 & 1.358 & 11.98 & 3.410 & 5.61 & 5.879 \\
\hline $\begin{array}{l}\text { Number of people in the } \\
\text { house }\end{array}$ & 11.07 & 4.897 & 8.77 & 2.614 & 10.12 & 4.253 \\
\hline Number of beef & 5.37 & 2.875 & 6.87 & 2.017 & 5.99 & 2.652 \\
\hline
\end{tabular}

Table3. Demographic and socio-economic characteristics of producers qualitative

\begin{tabular}{|l|l|l|l|l|l|l|}
\hline \multirow{2}{*}{$\begin{array}{l}\text { Qualitative } \\
\text { Variables }\end{array}$} & Conventional & Organic & \multicolumn{2}{l|}{ Together } \\
\cline { 2 - 7 } & Absolutefrequency & $\begin{array}{l}\text { Relative } \\
\text { frequency }\end{array}$ & Absolutefrequency & $\begin{array}{l}\text { Relative } \\
\text { frequency }\end{array}$ & Absolutefrequency & $\begin{array}{l}\text { Relative } \\
\text { frequency }\end{array}$ \\
\hline $\begin{array}{l}\text { Men } \\
\text { GenderWomen }\end{array}$ & 59 & 84.3 & 30 & 62.5 & 89 & 78.1 \\
\hline $\begin{array}{l}\text { Main activity } \\
\text { (Agriculture) }\end{array}$ & 52 & 11.4 & 17 & 35.4 & 25 & 21.9 \\
\hline Access to credit & 42 & 74.3 & 34 & 70.8 & 89 & 78.1 \\
\hline Education level & 13 & 58.6 & 16 & 33.3 & 57 & 50 \\
\hline
\end{tabular}

Our results show us that there is a big difference in sorting respondents by sex. In fact, it is mentioned that 
cotton production at our survey site is dominated by men with $78 \%$ against $21.9 \%$. this unequal classification of cotton producers by sex is also observed in the different cotton choices with $84.3 \%$ of men against $11.4 \%$ of women in conventional cotton production and $62.5 \%$ of men against $35.4 \%$ of women in production organic cotton. Depending on the age of the cotton producers, there is not a very big difference in cotton gender as was the case for sex .Conventional cotton producers and organic cotton producers have the following average ages 49 and 46 . The average age of cotton producers is 48 . The main activity of the people surveyed is agriculture (78.1\%), that is, agriculture which is practically their source of income. It is conventional cotton producers who practice more agriculture as their main activity with $74.3 \%$ against $70.8 \%$ of organic cotton producers. Notes that the number of agricultural activities is higher for cotton producers with an average of 9.06 against 8.51 on average for conventional cotton producers. For average of 8.74 for cotton producers. The number of people in the family is dominated by conventional cotton producers with an average of 11.07 against an average of 8.77 for organic cotton producers. All cotton producers have an average of 10.12 people are important in agriculture in Mali. In our study location, cotton producers do not have a very big difference in the number of beef with an average of 6.87 for organic cotton producers against 5.37 for conventional cotton producers. With an average of 5.99 for cotton producers in general. Also see that the cotton production fields are a bit far from the producers' homes. The fields are at an average distance of $4.28 \mathrm{~km}$ from the houses. This is the distance from organic cotton fields are greater with $4,457 \mathrm{~km}$ on average against $4,155 \mathrm{~km}$ on average for fields of conventional cotton producers. This difference in distances is explained by the fact that to cultivate organic cotton more need fertile land and that it is not very close to conventional cotton fields. Cotton producers as a whole have an experience of 15.5 years. It can be seen that conventional cotton producers have a very large number of average experience of (15.87 years) more than organic cotton producers with an average experience of (11.98 years). This difference in years of experimentation is explained by the fact that organic cotton is a new experimentation in cotton cultivation in Mali. In our area study the number of agricultural activists is much higher among organic cotton producers with 9.06 on average against 8.51 for conventional cotton producers. Because organic cotton producers do not produce a lot of cotton like conventional cotton producers. Regarding the financing of agricultural production, on the whole half have access and the other half do not have access to agricultural financing. It was found that conventional cotton producers have more access to agricultural credit of 58\% against cotton producers of $33.3 \%$. This gap is explained by the fact that the Malian state wants to encourage farmers who have adopted cotton cultivation. Education is very important in agriculture, especially in cotton production. We can see that organic cotton producers are more numerous with $43.8 \%$ plus conventional cotton producers with $18.6 \%$. Organic cotton producers are more aware of the effects of chemicals used by conventional cotton producers, which is one reason for this difference in numbers.

\subsection{Estimation of the Logistic Regression Model}

The results from the estimation model are presented in Table4:

Table4 Results of the estimation model

\section{Variables in the Equation}

\begin{tabular}{|c|c|c|c|c|c|c|c|}
\hline & & $B$ & S.E. & Wald & df & Sig. & $\operatorname{Exp}(B)$ \\
\hline \multirow[t]{2}{*}{ Step $1^{a}$} & NBeef & .240 & .091 & 6.976 & 1 & .008 & 1.271 \\
\hline & Constant & -.455 & .528 & .742 & 1 & .389 & .635 \\
\hline \multirow[t]{3}{*}{ Step $2^{b}$} & Sexe(1) & 1.355 & .670 & 4.096 & 1 & .043 & 3.877 \\
\hline & NBeef & .244 & .092 & 6.955 & 1 & .008 & 1.276 \\
\hline & Constant & -.707 & .551 & 1.648 & 1 & .199 & 493 \\
\hline
\end{tabular}

a. Variable(s) entered on step 1: NBeef.

b. Variable(s) entered on step 2: Sexe.

Model if Term Removed

\begin{tabular}{|ll|r|r|r|r|}
\hline \multicolumn{2}{|l|}{} & \multicolumn{1}{|c|}{$\begin{array}{c}\text { Model Log } \\
\text { Likelihood }\end{array}$} & $\begin{array}{c}\text { Change in -2 } \\
\text { Log } \\
\text { Likelihood }\end{array}$ & \multicolumn{1}{c|}{$\begin{array}{c}\text { Sig. of the } \\
\text { Change }\end{array}$} \\
\hline Step 1 & NBeef & -68.591 & 7.903 & 1 & .005 \\
Step 2 & Sexe & -64.640 & 5.092 & 1 & .024 \\
& NBeef & -66.051 & 7.914 & 1 & .005 \\
\hline
\end{tabular}


The probability $\mathrm{P}$ of the model being equal to $0.000 . *$-Which shows us that the model is entirely significant at only $1 \%$. The results of the model especially the signs can be considered andare therefore credit. The results retained in the preceding table indicate that 2 variables act significantly on the reasons for the adaptation of organic cotton to our study region. The variables that act are: the sex of the producers (SEX), number of beef from producers (NBeef). Regarding the age of producers (AGE), the number of people in the family (NPF), the main activity (AP), Access to agricultural credit (AAC), education level of producers (Ed), number of agricultural activity (NAA), distance between house and fields (DHF), cotton experience (ECP) variables, these variables do not have a significant effect on the adoption of organic cotton.

\section{Discussion}

The sex of the producers (SEX):

The gender of the producers acts positively and significantly (at the 5\% threshold) in the adoption of organic cotton. The organic cotton product is dominated by women in that there is no handling of chemicals and it allows them to fall a little financially. This is not the same for the production of conventional cotton where everything is controlled by the heads of the household, usually the husband. In addition, women do not have a lot of time to maintain a space because of their managerial occupation. These results reinforce those obtained by other researchers like who have proven that women are better at producing organic cotton.

\section{Number of beef:}

It was found that the number of oxen positively influences the adoption of organic cotton and of significant handling at the only of (at the 10\% threshold) in our study area. The oxen facilitate transport because the organic cotton fields are not very close to the houses. The more oxen we have, the more natural fertilizer we can have.

\section{Conclusion}

There was some evidence that was thought to be influencing the adoption of organic cotton. Among these elements there are 2 that significantly influence the adoption of organic cotton. We have the number of beef, the gender of the producers have a positive influence on the adoption of organic cotton.

\section{References}

Altenbuchner, C., Larcher, M., \& Vogel, S. (2016). The impact of organic cotton cultivation on the livelihood of smallholder farmers in Meatu district, Tanzania. Renewable Agriculture and Food Systems, 31(1), $22-36$. https://doi.org/10.1017/S1742170514000416

Arslan, A., McCarthy, N., Lipper, L., Asfaw, S., \& Cattaneo, A. (2014). Adoption and intensity of adoption of conservation farming practices in Zambia. Agriculture, Ecosystems and Environment, 187, 72-86. https://doi.org/10.1016/j.agee.2013.08.017

Assogba, S. C. G., Tossou, R. C., Lebailly, P., \& Magnon, Y. (2014). Sustainable intensification of agriculture in Benin: myth or reality? Lessons from organic and cotton made in Africa production systems. International Journal of Agriculture Innovations and Research, 2(5), 694-704.

De Guimaraes, J. C. F., Severo, E. A., \& Dorion, E. C. H. (2014). Cleaner production and environmental sustainability: Multiple case from serra gaúcha-Brazil. Espacios, 35(4).

Deshpande, T. (2017). STATE OF AGRICULTURE IN STATES OF AGRICULTURE IN INDIA. In PRS Legislative Research: Vol. March (Issue 113). https://www.prsindia.org/uploads/media/Analytical Report/State of Agriculture in India.pdf

Eichelberger, M. C. (2007). The cotton rat as a model to study influenza pathogenesis and immunity. In Viral Immunology (Vol. 20, Issue 2, pp. 243-249). https://doi.org/10.1089/vim.2007.0017

Farooq, O., Mubeen, K., Khan, A. A., \& Ahmad, S. (2020). Sowing methods for cotton production. In Cotton Production and Uses: Agronomy, Crop Protection, and Postharvest Technologies (pp. 45-57). https://doi.org/10.1007/978-981-15-1472-2_4

Ge, F., Liu, X., Li, H., Men, X., \& Su, J. (2003). Effect of nitrogen fertilizer on pest population and cotton production. Chinese Journal of Applied Ecology, 14(10), 1735-1738.

Holcombe, S. H., Ali Nawaz, S., Kamwendo, A., \& Ba, K. (2004). Managing development: NGO perspectives? International Public Management Journal, 7(2), 187-205.

Holland, M. D., \& Gray, B. R. (2011). Multinomial mixture model with heterogeneous classification probabilities. Environmental and Ecological Statistics, 18(2), 257-270. https://doi.org/10.1007/s10651-009-0131-2

Lakhal, S. Y., H’Mida, S., \& Sidibé, H. (2005). Organic cotton supply chain compared to a cotton supply chain. Proceedings of the 35th International Conference on Computers and Industrial Engineering, ICC and IE $2005,1265-1272$.

Li, J., Lai, X., \& Yu, Z. (2013). A paired combinatorial logit route choice model with probit-based equivalent impedance. Journal of Transportation Systems Engineering and Information Technology, 13(4), 100-104. https://doi.org/10.1016/S1570-6672(13)60119-1 
Métouolé Méda, Y. J., Egyir, I. S., Zahonogo, P., Jatoe, J. B. D., \& Atewamba, C. (2018). Institutional factors and farmers' adoption of conventional, organic and genetically modified cotton in Burkina Faso. International Journal of Agricultural Sustainability, 16(1), 40-53. https://doi.org/10.1080/14735903.2018.1429523

Nguyen, T. A. H., Ngo, H. H., Guo, W. S., Zhang, J., Liang, S., Yue, Q. Y., Li, Q., \& Nguyen, T. V. (2013). Applicability of agricultural waste and by-products for adsorptive removal of heavy metals from wastewater. Bioresource Technology, 148, 574-585. https://doi.org/10.1016/j.biortech.2013.08.124

Prashanth, P., Reddy, M. J. M., \& Rao, I. S. (2013). Organic cotton farming in Andhra Pradesh - a constraint analysis. Journal of Cotton Research and Development, 27(1), 138-143. http://www.crdaindia.com

Sodjinou, E., Glin, L. C., Nicolay, G., Tovignan, S., \& Hinvi, J. (2015). Socioeconomic determinants of organic cotton adoption in Benin, West Africa. Agricultural and Food Economics, 3(1). https://doi.org/10.1186/s40100-015-0030-9

Tayade, A. S., \& Dhoble, M. V. (2010). Effect of nutrient and pest management modules on incidence of bollworms complex of transgenic bt cotton. Pestology, 34(3), 30-41.

Wilson, J. R., \& Lorenz, K. A. (2015). Hierarchical Logistic Regression Models (pp. 201-224). https://doi.org/10.1007/978-3-319-23805-0_10

World Bank. (2016). Agriculture, value added (\% of GDP). Data, 1-19. http://data.worldbank.org/indicator/NV.AGR.TOTL.ZS 